\title{
Estudo dos Micropezídeos da Bacia Amazônica. III-Conhecimento de uma nova espécie e redescrição de três espécies de Taeniaptera Macquart, 1835 (Diptera - Micropezidae)
}

\author{
Lindalva Paes de Albuquerque ${ }^{2}$ ]
}

\section{Resumo}

Prossegue-se os estudos de Taeniaptera Macquart, 1835, com a redescrição de T. albibasis (Enderlein, 1922); T. angulata (Loew, 1866); T. annulata (Fabricius, 1787) e descrição de uma espécie nova para a ciência T. teresacristinae, com base na morfologia externa e anatomia da genitália de ambos os sexos. A distribuição geográfica do gênero está concentrada na faixa tropical americana. A ocorrência destas espécies em estudo, abrange vários tipos de habitats amazônicos.

\section{INTRODUÇÃO}

$\mathrm{Na}$ redescrição das espécies, objetiva-se complementar o estudo da morfologia externa, das descriçōes originais e de outras subse. qüentes. O conhecimento da anatomia da genitália, onde há caracteres altamente significativos e de valor sistemático, permite, através de diferenciações morfológicas de suas peças, uma determinação segura ao nível especifico.

As espécies conhecidas e hoje contidas no gênero Taeniaptera, na sua maioria foram descritas originalmente em outro gênero: $T$. albıbasis (Enderlein, 1922) como Grallomya albibasis Enderlein, 1922:216-217; T. angulata (Loew, 1866) como Calobata angulata Loew, $1866: 87 ; T$. annulata (Fabricius, 1787), como Musca annulata Fabricius, $1787: 338$. A nova espécie teresacristinae e aquelas aqui redescritas, são bem individualizadas na coloração, quetotaxia e tamanho total; convergem porém na semelhança de alguns caracteres de menor valor sistemático e pela constância na presença da célula posterior da asa aberta e no quinto esternito do macho, com apófise basal, o que permite ser considerado um conjunto na- tural que passará a se chamar grupo III, dentro do gênero.

\section{MATERIAL E MÉTODOS}

As coletas desses dipteros foram feitas com rede entomológica quando em capturas diretas, com auxílio de armadilha, de acordo com Vanzolini et al., 1967. Para determinação das espécies, fez-se estudo através de dissecções de exemplares, para preparação de lâminas e desenhos de estruturas da genitália dos machos e fêmeas. Segue-se assim, o método clássico adotado em Entomologia, para estudos sistemáticos com base na morfologia. Os exemplares identificados, conservados a seco e no álcool a $70 \%$ e as lâminas em montagens definitivas, estão depositados na Coleção Entomológica do INPA.

\section{Resultados}

Pelo exame comparativo do material disponível com as descrições originais, pelas fotos e figuras contidas na biblicgrafia, acredita-se válida a posição de cada espécie. A sinonimia completa encontra-se no início de cada redescrição. Completam-se aqui, dez espécies analisadas através de observações detalhadas da morfologia externa e do estudo comparativo da anatomia da genitália, em ambos os sexos.

\section{DESCRIÇÃO DAS ESPÉCIES}

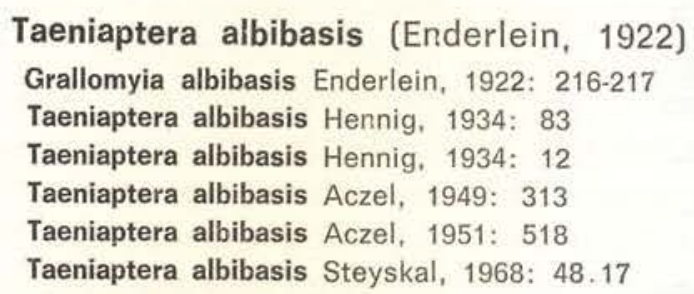

(1) - Parte da tese submetida a julgamento pelo Instituto Nacional de Pesquisas da Amazônia-INPA e Fundação Universidade do Amazonas - FUA, para obtenção do grau de Mestre em Ciências Biológicas em 27.11.79.

(2) - Instituto Nacional de Pesquisas da Amazônia, Manaus. 


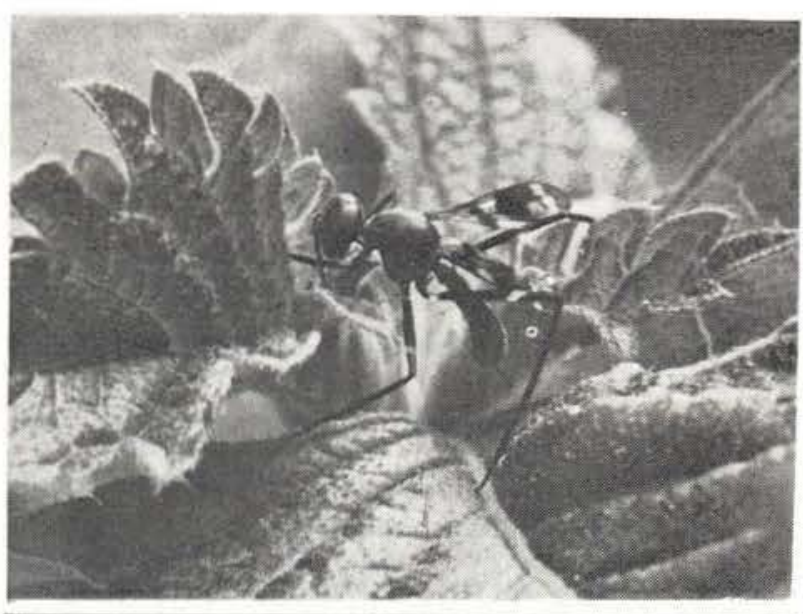

Fig. 1 - Taeniaptera albibasis (Enderlein, 1922). Exemplar macho.

Macho - Comprimento en média de 9.0 $\mathrm{mm}$. Corpo castanho enegrecido. Cabeça (Fig. 2) subglobosa. Mesofronte ligeiramente protuberante, fusiforme, castanha, superficie fracamente rugosa, brilhante; mancha castanhoescura aveludada, envolvendo o triângulo ocelar, borda anterior castanho-clara amarelada. Frontália castanho-brilhante. Parafrontália bem delimitada, anteriormente entumescida. Epicephala e Paracephala castanho-escuras, com pruinosidade prateada que se condensa próximo às genas. Occiput castanho com setas que se concentram próximo à inserção do pescoço. Gena em uma faixa contínua, densa pruinosidade prateada marginando os olhos, próximo à abertura bucal 4 setas desenvolvidas $e$ duas rudimentares. Parafacialia castanho-clara e micropêlos escassos, faixa castanhosescura marginando a abertura bucal. Peças bucais: anteclípeo castanho, tênue pruinosidade prateada concentrando-se lateralmente. Palpos labiais castanho-enegrecidos, terço apical e margem anterior claros. Labelo castanho-claro com pequenos pêlos. Premento castanho com pequenas setas superficiais que se concentram na margem anterior. Antena: esclerito basilar castanho brilhante, primeiro e segundo segmento castanho-claro com pequenas setas distribuidas na superfície e concentradas na margem distal. Segmento III o mais desenvolvido, castanho-escuro, com pilosidade e base claras. Arista dorsal, clara na base escurecendo distalmente. Setas da cabeça: 1 orsa ligei- ramente paralelas, subiguais 1 orss fracamente divergente, 1 vta ligeiramente reclinada, 1 vte fracamente divergente e 1 vti divergente. 1 pvt paralelo.

Tórax - dorsalmente cinza escuro com reflexos ferruginosos. Calo umeral castanhoclaro. Propleura ligeiramente amarela. Esternopleura castanho-escura com reflexos de pruinosidade cinza. Setas torácicas: 7 propleurais, 2 pares dorsocentrais, 2 pares notopleurais subiguais, ligeiramente reclinados, 1 par supralar e 1 par pósalar. Pente esternopleura: com 15 setas desenvolvidas e pêlos adicionais. Asa conf. (Fig. 3) em média 7,50mm de comprimento por $2,32 \mathrm{~mm}$ de largura. Célula pos terior aberta. Manchas claras e escuras com limites bem nítidos, largura e forma características, mancha hialina arredondada na $m-c u$. Pernas: coxas I, II e Ili castanho-escuras com pruinosidade prateada e pequenas cerdas marginais. Primeiro par castanho-escuro; fêmur clareando distalmente. Segundo par castanho-escuro; base do fêmur branca, anel claro distomediano em diagonal, na proporção de $1 / 1$ da largura do fêmur, clareando para a extremidade; tíbia e tarsos castanho-escuros. Terceiro par castanho-escuro; base do fêmur clara, anel distomediano em diagonal, claro, $1 / 1$ da largura do fêmur, ápice mais claro; tíbia e tarsos 2 e 3 escuros, o restante dos tarsos claros. Halter (Fig. 4).

Abdome - (Fig. 5) Tergitos: I e II formando uma peça única maior que o comprimento de III a VI. O tergito I é coberto por pêlos longos e claros que formam fila nas margens laterais e a fila posterior a um terço do sulco da união dos dois segmentos; faixas transversas de densa pruinosidade se estendem até o tergito II. Do tergito II ao VI há pequenas setas escuras, superficiais que se alinham também na margem posterior, limitando uma faixa clara membranosa. Membrana intersegmentar castanho-escura, intercalada de manchas claras, a primeira vai dos tergitos I + II ao esternito III; a segunda do tergito V ao esternito VI. Pruinosidade clara na membrana escura do tergito III. Esternitos: (Fig. 6) o I com pêlos claros e longos, o esternito II com área basal mediana membranosa, o III e IV reduzidos a es- 


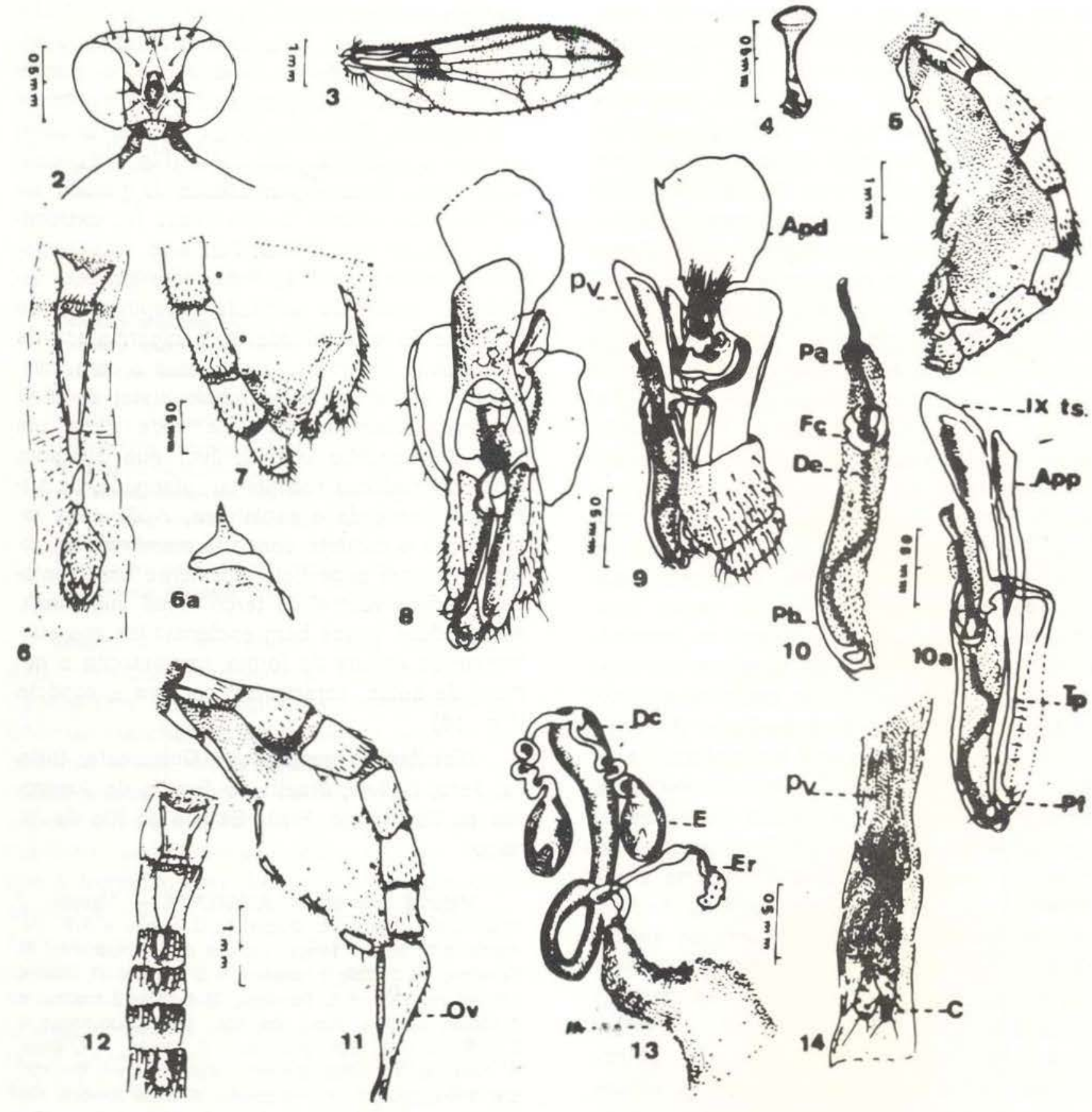

Fig. 2-14 - Taeniaptera albibasis (Enderlein, 1922). Macho: 2 - cabeça, vista dorsal; 3 - asa; $4-$ halter; $5-$ abdome, vista lateral esquerda; 6 - esternitos de I-V; 7 - esternitos VI e VII; 8 - genitália, vista lateral esquerda; 10 - edeago; 10a - detalhe da genitália. Fêmea: 11 - abdome, vista lateral esquerda; 12 - esternitos I-VI; 13 genitália, dutos e espermatecas; $14-$ genitália, porçăo distal. (Apd = apódema do ducto; App = apódema do edeago; $\mathrm{Dc}=$ ducto comum; $\mathrm{De}=$ ducto ejaculador; $\mathrm{E}=$ espermateca; $\mathrm{Er}=$ espermateca rudimentar; $\mathrm{Fc}=$ formação capsular; $\mathrm{M}=$ membrana; $\mathrm{Ov}=$ ovipositor; $\mathrm{Pa}=$ porção apical; $\mathrm{Pb}=$ porção basal; $\mathrm{Pf}=$ pinças fálicas; $\mathrm{Tp}=$ teca do pênis; IX st. = nono esternito).

treitas traves, esternito $\mathrm{V}$ o mais desenvolvido, côncavo, bifurcado na margem distal com finas setas superficiais e robustos espinhos nas margens internas atingindo o ápice. $\mathrm{Na}$ base desses braços, dorsalmente duas pequenas apófises com setas e espinhos terminais. Esternito VI, é uma placa afilada na base, a mar. gem distal une-se ao esternito VII estreita tra. 
ve que se alonga na face esquerda, indo tocar o tergito VII que é reduzido e de posição late. ral. Epândrio castanho claro (Fig. 7) coberto de pequenos pêlos escuros e claros, com fina pruinosidade cinza. Cercos ocupam quase toda a margem distal, com pêlos claros e escuros que se condensam nas bordas. Genitália conforme (Fig. 8) esternito IX, com base formada por um anel incompleto, extremidacies em apófises que se alongam no sentido basilar do segmento, unindo-se na porção mediana, formando uma placa que forra a superfície ventral. Essas apófises estendiam-se no sentido distal indo articular-se às extremidades laterais do tergito IX. Apodema do pênis de base alargada, esclerosada e encurvada longitudinalmente, com ligeiras estrias transversas no sentido distal. Alongando-se em forma de calha quitinosa na face dorsal e laterais membranosas, forma um tubo finamente ornamentado que constitui a teca do pênis, esta sustenta lateralmente, a um terço da extremidade distal, dois braços que terminam nas pinças fálicas, com um par de setas na superfície encurvacia. A extremidade distal da peça une-se, por meio de um anel incompleto, à porção basilar do falo, sustentada por uma trave dorsal quitinosa que se prende à membrana, finamente ornamentada em toda extensão; termina em uma formação capsular forte e esclerosada que sustenta a extremidade do falo, membranosa e curta. Lateralmente ao apódema do pênis fica o apódema do duto ejaculador, muito consistente (Fig. 9), base capsular alargada e borda estriada, na base se evidencia uma glândula em forma de cacho. O pedúnculo do apódema continua no sentido basilar do segmento, alargando-se progressivamente em forma de leque e tornando-se despigmentado e transparente. Em posição lateral da cápsula, sai o duto ejaculador, de diâmetro moderado, passa pela teca e pelo anel de articulação, acompanha o segmento basilar do falo, atravessa a formação capsular e reaparece formando o ápice, envolto em membrana (Fig. 10).

Fêmea - Comprimento em média $9.3 \mathrm{~mm}$, idêntica ao macho na morfologia, diferindo apenas no maior tamanho do corpo, as asas têm em média $7.43 \mathrm{~mm}$ de comprimento. Abdome conforme (Fig. 11), com micropêlos e es. parsa pruinosidade na face dorsal, e pequenas setas que se alinham na margem posterior dos tergitos. Esternitos (Fig. 12), do terceiro ao quinto vestigial. Genitália (Fig. 13), conduto comum das espermatecas de parede reforçadas por estrias transversas. Na extremidade basilar do conduto, forma-se uma ampola que reduz o calibre, dividindo-o em dois tubos de superfície estriada e espinhosa que sustenta na extremidade uma espermateca de forma oval, ligeiramente enrugada e com inva. ginação apical. A extremidade distal do duto encurvada ventraimente e de onde parte um tubo de tamanho considerável que sustenta uma espermateca rudimentar, alongada, de superfície enrugada e espinhosa. Após essa ra. mificação o conduto continua membranoso, dilatado e com superfície ricamente ornamentada. $\mathrm{Na}$ face ventral do terço distal individualizam-se duas traves bem esclerosadas que sustentam os cercos de forma, implantação e nú. mero de setas, característicos para a espécie (Fig. 14).

Distribuição geográfica: Guatemala, Guiana, Peru, Bolívia, Brasil: do Estado do Amazonas ao Estado do Pará, Estado do Rio de Janeiro.

Material examinado: AMAZONAS - Manaus: 2 machos e 1 fêmea, R. Ducke, M.C. Mello e F.B. Almeida, 6.3.1968; 1 fêmea, Estrada do Aleixo-Pomar, A. Faustino, 30.3.1968; 3 machos e 2 fêmeas, R. Ducke, L.P. Albuquerque e A. Faustino, 29.4.1968; 2 machos e 1 fêmea, Estrada Am-1 Km 104, L.P. Albuquerque e E.V. Silva, 13.5.1968; 3 fêmeas, R. Ducke, E.V. Silva, A. Faustino, 4.7.1968; 1 macho, Estrada Am-1 Km 155, E.V. Silva, 12-25.7.1968; 1 macho, Estrada Am-010, Km 184, E.V. Silva e A. Faustino, 28.7.1968; 1 fêmea, Estrada Am-1, Km 79, E.V. Silva e A. Faustino, 1.8.1968; 2 machos e 2 fêmeas, R. Ducke, A. Faustino e E.V. Silva, 2.8.1968; 1 macho, A. Faustino, 4.6.1968; 1 fêmea, Estrada Aleixo-Mauá, E.V. Silva, 4.7.1969; 1 fêmea, Estrada BR-174 (antiga BR-17), E.V. Silva, 10.8.1969; 2 fêmeas, R. Ducke, L.P. Albuquerque, 4.7.1970; 1 fêmea, Estrada Am-1 Km 15, A. Faustino, 17.7.1970; 1 fêmea, Colônia St. Antonio, A. Faustino, 31.07.1970; 1 fêmea, Reserva Ducke, T. Pimentel, 1-5.7.1970; 1 fêmea, INPA, I.S. Goyareb, 7.4.1977; 1 macho, BR-174, NAF-6, Km 31, L.P. Albuquerque, 27.5.1977; 1 fêmea, Estrada Am-1 $\mathrm{Km} \mathrm{31}$, L.P. Albuquerque, 18-19.8.1977; 3 fêmeas e 3 machos, R. Ducke, L.P. Albuquerque, 13-15.1.1978; 1 macho e 2 fêmeas, L.P. Albuquerque; 1 macho, R. Duc- 
ke, Orieta Rodrigues e A. Soares, 24.1.1978; PARÁ 1 macho, Utinga, H.S. Lopes, W. Miranda, 22.6.1965; 1 macho, Mocambo, H.S. Lopes e W. Miranda, 1.7.1965, 1 macho, Belém-Bragança, $\mathrm{Km} \mathrm{100,} \mathrm{H.S.} \mathrm{Lopes,}$ 13.7.1965; 2 machos, Mocambo, T. Pimentel, 6-7.8.1970; 1 fêmea, Apauá Boa Vista, I.S. Goyareb, 18.7.1974; 1 macho, Belém-Brasilia, Km 90, M.F. Torres, 23.2.1976. ESTADO DO RIO DE JANEIRO - 1 fêmea, Palmeiras, H.S. Lopes, 7.1.1939; 1 fêmea, Grajaú, H.S. Lopes, 14.3.1939.

Taeniaptera angulata (Loew, 1866)

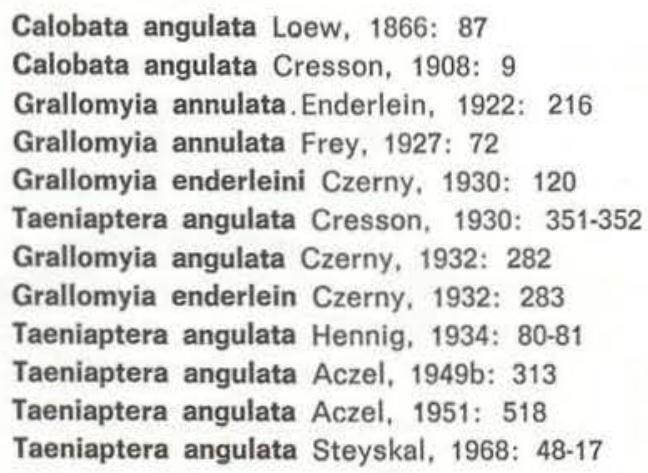

Macho - Comprimento total em média $9,40 \mathrm{~mm}$. Cor basicamente castanho-escura. Cabeça (Fig. 15) subglobosa. Mesofronte fusiforme, mancha escura-aveludada anterior ao triângulo ocelar, castanha-escura brilhante com ocelos claros. Frontália castanho-avermelhada, clareando para a porção anterior. Parafrontália castanha, ligeiramente protuberante em relação à frontália. Occiput castanho-escuro com pequenos pêlos que se concentram na margem do pescoço. Gena com pruinosidade clara marginando os olhos. Próximo à abertura bucal 4 setas mais desenvolvidas e setas pequenas adicionais. Parafacialia estreita coberta de pruinosidade prateada. Lâmina mesofacial castanho-clara, micropelos e fina pruinosidade superficial. Antena: esclerito basilar castanho-clara brilhante primeiro e segundo artículo, castanho-clara com pequenas setas marginais e uma bem desenvolvida na face ventral, terceiro artículo o mais desenvolvido e escuro, coberto de pilosidade clara com reflexos prateados. Arista, clara na base escurecendo para a extremidade. Fossa antenal castanho-clara brilhante. Peças bucais: clípeo castanho moderado com reflexos prateados. Palpos labiais castanho-escuros com pêlos escuros e margem anterior clara. Labelo castanho- claro amarelado. Premento castanho-escuro, pequenas setas distribuídas e as mais desenvolvidas na margem anterior. Setas da cabeça: 1 par orsa fracamente divergente, 1 par orss paralelo, 1 par vta ligeiramente proclinado, 1 par vte divergente, 1 par vti também divergente, 1 par pvt ligeiramente paralelo.

Tórax - Noto castanho-escuro com fina pruinosidade dourada. Calo umeral castanhoclaro. Propleuras com pêlos finos e na esternopleura pruinosidade prateada. Setas do tórax: fila de 7 propleurais, 2 pares notopleurais sub-iguais, 1 par supralar e 1 par pósalar, 1 par dorsocentral pré-escutelar, 1 par escutelar apical fracamente convergente; pente esternopleural formado de 15 setas marginais mais desenvolvidas e setas menores adicionais. $\mathrm{Na}$ face inferior da estérnopleura anterior à inserção da segunda coxa, há de três a seis cerdas enfileiradas. Asa (Fig. 16) com 7,1 mm de comprimento por $2,0 \mathrm{~mm}$ de largura média, faixas escuras transversais, sub-basilar estreita, mediana a mais larga, e a mancha subapical tem bordas convexas, sobre a veia $\mathrm{m}+\mathrm{cu}$ área hialina, circular bem delimitada em todos exemplares examinados. Pernas: coxas I, II e III, castanhos, pruinosidade prateada, setas marginais anteriores. Perna I: fêmur castanho, clareando no terço distal; tíbia igualmente castanha; tarsos brancos excetuando a base do tarso I castanha. Perna II e III: fêmur castanho, tendo a base do anel subapical amarelada, terço distal castanho claro; tíbia e tarsos castanhos sendo os dois últimos tarsos mais claros. Halter (Fig. 17).

Abdome - (Fig. 18) castanho-escuro. Tergitos: tergito I coberto de pêlos claros desenvolvidos, e pêlos maiores marginais; o sulco de junção com o tergito II é marcado por uma forte camada de pruinosidade prateada. Do tergito II ao V a superfície apresenta pequeninas cerdas que também se alinham na margem posterior que é marcada por estria clara. Os ângulos posteriores marginais do tergito II são mais alargados, com a área esclerosada e bem pigmentada. Esternitos: esternito I base alargada estreitando-se distalmente onde se une ao esternito II por uma área membranosa mediana; os esternitos III e IV reduzidos a estrei- 


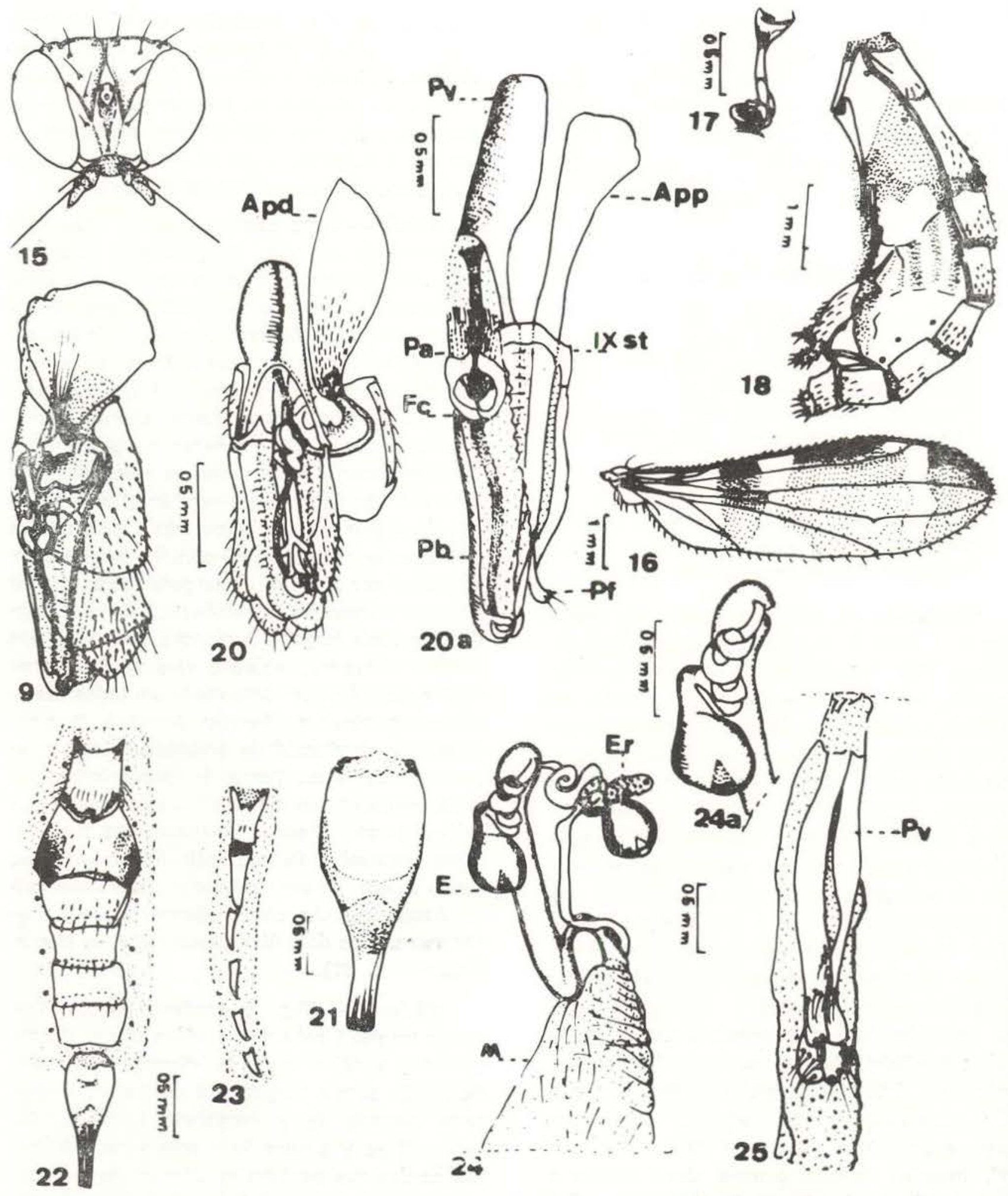

Fig. 15-25 - Taeniaptera angulata (Loew, 1866). Macho: 15 - cabeça, vista dorsal; 16 - asa; 17 - halter: $18-$ abdome, vista lateral esquerda; 19 - genitália, vista lateral esquerda; 20 - genitália, vista ventral; $20 \mathrm{a}$ - detalhe da genitália. Fêmea: 21 - ovipositor; 22 - tergitos, vista dorsal; 23 - esternitos I-VI: 24 - genitália, dutos e espermatecas; $24 a-$ espermateca funcional; 25 - porçāo distal da genitália. (Apd = apódema do ducto; App = apódema do edeago; $\mathrm{Dc}=$ ducto comum; $\mathrm{De}=$ ducto ejaculador; $\mathrm{E}=$ espermateca; $\mathrm{Er}=$ espermateca rudimentar; $\mathrm{Fc}$ = formação capsular; $\mathrm{M}=$ membrana; $\mathrm{OV}=$ ovipositor; $\mathrm{Pa}=$ porção apical; $\mathrm{Pb}=$ porção basal; $\mathrm{Pf}=$ pinça fálica; $\mathrm{Tp}=$ teca do edeago; $\mathrm{IX}$ st $=$ nono esternito). 
tas traves marginadas por um sulco e com finas setas superficiais e marginais; esternito $\mathrm{V}$ com extremidades bifurcadas e ligeiramente convergentes tendo na face interna espinhos curtos e robustos e setas desenvolvidas que se condensam nas extremidades. Na base dessas bifurcações, dor'salmente ficam duas apófises curtas de extremidade espinhosa. Esternito VI estreito na base, que se insere sob o esternito $\mathrm{V}$ servindo-lhe de suporte, a margem distal une-se ao esternito VII estreito com extremidade esquerda indo tocar o VII tergito, rudimentar e de posição lateral em relação aos demais tergitos. Epândrio castanho-claro, finas setas superficiais reduzidas, pilosidade clara, pequenas setas que se condensam nas margens: a margem distal é quase totalmente ocupada pelos cercos bem constituídos, com setas superficiais e marginais. Genitália: IX esternito formando um anel incompleto (Fig. 19), das extremidades desse anel formam-se pequenas apófises que se ligam aos prolonga. mentos laterais do tergito IX que lhe serve de suporte; na direção distal continuam-se em duas traves largas que se unem na altura mediana formando uma placa consistente, em for$\mathrm{m}$ de calha, esclerosada na porção dorsal e as laterais membranosas, que é a teca do falo. Do terço distal da teca partem dois braços la. terais, que sustentam na extremidade as pinças fálicas, pequena placa curva, com um par de setas superficiais. A extremidade da teca articula-se à porção basal do falo, por meio de uma placa estreita, encurvada, incompleta na face ventral. A porção basilar do falo é membranosa, sustentada por uma trave dorsal quitinosa, bifurcada para o ápice, que termina em uma formação quitinosa, capsular, complexa, que sustenta a porção terminal. Apódema do duto ejaculador; área basilar alargada e bordas estriadas, continua em um pedúnculo fortemente esclerosado e pigmentado na base onde se observa uma formação glandular em cacho. Na direção da base do segmento o pedúnculo é progressivamente alargado e despigmentado. De um lado da cápsula basilar parte o duto ejaculador, tubo que corre pela teca, passa no anel de articulação, continua pela porção basilar do falo, atravessa a forma- ção capsular e vai formar a parte terminal (Fig. 20).

Fêmea - Comprimento em média de 10,50 $\mathrm{mm}$. Morfologia idêntica a do macho, diferindo somente no tamanho que é ligeiramente maior, conseqüentemente as asas em média têm $7,6 \mathrm{~mm}$ de comprimento por $2,4 \mathrm{~mm}$ de largura. Ovipositor castanho-escuro brilhante, estreitando-se no terço distal (Fig. 21). Tergitos conforme Fig. 22, face convexa, fina ca. mada de pruinosidade prateada. Esternitos (Fig. 23). Genitália: espermatecas bem desen. volvidas. Duto comum alongado na base uma ampola que reduz o calibre, dividindo-o em dois pedúnculos ligeiramente dilatados com circunvoluções acentuadas, sustentando na extremidade espermateca oval de superfície ligeiramente enrugada e pequena invaginação apical. $\mathrm{O}$ duto comum diminui de calibre após o terço basilar e o terço distal é encurvado conforme fig. 24. Do duto parte um tubo de calibre reduzido que sustenta uma espermateca rudimentar, alongada, esclerosada e de superfície espinhosa. $O$ duto comum continua em largo tubo membranoso enrugado, com duas traves quitinosas que ocupam a face ventral, sustentando na extremidade os cercos bem delimitados com tamanho e número de cerdas característico para a espécie. (Fig. 25).

Distribuição geográfica conhecida: Honduras, Nicaragua, Costa Rica, Panamá, Colômbia, Venezuela, Guiana Francesa e Suriname, Brasil, (Estados: Amazonas, Pará, Rio de Janeiro, Minas Gerais e Mato Grosso), Peru, Bolívia e Argentina.

Material examinado: T. angulata - AMAZONAS 1 macho e 3 fêmeas, Estrada do Aleixo-Mauá, A. Faustino, 30.3.1968; 1 macho, R. Ducke, L.P. Albuquerque e A. Faustino, 29.4.1968; 1 macho, Estrada do AleixoMauá, E.V. Silva, V. 1968; 1 macho e 2 fêmeas, Estrada do Aleixo-Mauá, E.V. Silva, 26.6.1968; 2 fêmeas, R. Ducke, A. Faustino, E.V. Silva, 26.6.1968; 2 fêmeas, R. Ducke, A. Faustino, E.V. Silva, 3.7.1968; 1 macho e 1 fêmea, R. Ducke, 4.7.1968, E.V. Silva e A. Faustino; 1 fêmea, Estrada AM-01 Km 182, E.V. Silva, A. Faustino, 9.7.1968; 1 macho, Estrada AM-01 Km 155, E.V. Silva e A. Faustino, 11.7.1968; 1 macho e 1 fêmea, R. Ducke, E.V. Silva, A. Faustino, 3.8.1968; 1 fêmea, R. Ducke, E.V. Silva, A. Faustino, 5.8.1968; 1 fêmea, R. Ducke, A. Faustino, 14.9.1968; 1 macho, R. Ducke, A. Faustino, 20.11.1968; 2 machos e 3 fêmeas, Aleixo-Mauá, E.V. Silva, 4.7.1969; 1 fêmea, Estrada BR-174 (antiga 
BR-17), E.V. Silva, 10.7.1969; 2 machos e 2 fêmeas, Estrada AM-1 Km 16, E.V. Silva, 17-19.7.1969; 1 macho e 1 fêmea, Estrada BR-174 (antiga BR-17) Km 7, E.V. Silva, 5.8.1969; 2 fêmeas, Estrada BR-174 (antiga BR-17) Km 7, E.V. Silva, 12.8.1969; 5 fêmeas e 7 machos, R. Ducke, A. Faustino, 14.8.1969; 3 fêmeas, Estrada AM-1, $\mathrm{Km} \mathrm{15,} \mathrm{A.} \mathrm{Faustino,} \mathrm{14.9.1969;} 1$ fêmea, R. Ducke, L.P. Albuquerque, 4.7.1970; 1 macho e 1 fêmea, Sto. Antonio, A. Faustino, 27.7.1970; 1 macho e 6 fêmeas, Estrada AM-1, Km 15, A. Faustino, 27.7.1970; 1 macho e 6 fêmeas, Estrada AM-1, Km 15, 28-31.7.1970; 1 macho, Col. Sto. Antonio, T. Pimentel, 10.8.1970; 1 macho e 2 fêmeas, R. Ducke, T. Pimentel, 19-21.8.1970; 1 macho, Estrada AM-1, Km 64, A. Faustino, 24.8.1970; 1 macho, Campus do INPA, A.P.A. Luna, 2.3.1979; 1 macho, Campus do INPA, A. Luna, 29.4.1976; 1 fêmea, Campus do INPA, E. Rufino, 30.4.1976; 1 fêmea, S. Francisco, B. Mascarenhas, 10.6.1976; 1 fêmea, Faz. NAF-6, Km 31, BR-174, Mário Dantas, 30.4.1976; 3 fêmeas, AM-1, $\mathrm{Km}$ 232, L.P. Albuquerque, 30.4.1977; 1 macho, Campus do INPA, M. Mendonça, 6.6.1977; 1 fêmea, R. Ducke, L.P. Albuquerque, 8.6.1977; 1 macho e 2 fêmeas, Estrada AM-1, $\mathrm{Km}$ 31, L.P. Albuquerque, 18 9.1977; 1 macho, Reserva de Campina, Estrada BR174, $\mathrm{Km}$ 62, L.P. Albuquerque, 21.9.1977; 4 fêmeas, R. Ducke, Mn. AM. L.P. Albuquerque, 14-15.1.1978; 1 fêmea, R. Ducke, O. Rodrigues, A. Brito, 24.1.1978. Tabatinga, 1 fêmea, A. Faustino, 3.9.1969. PARA - Belém, 2 fêmeas, Mocambo, H.S. Lopes, 18.7.1937. RIO DE JANEIRO - 1 fêmea, Nova Iguaçu, W. Miranda, W. 76-051.1946; 1 fêmea, Manguinhos, IOC, H.S. Lopes, $\mathrm{s} / \mathrm{d}$. MINAS GERAIS - 1 fêmea, Lasance, Martins, Lopes, 31.1.1939. MATO GROSSO - 1 fêmea, Aripuanä, Reserva Humboldt, Bento Mascarenhas, 17-19.3.1977.

\section{Taeniaptera annulata (Fabricius, 1787)}

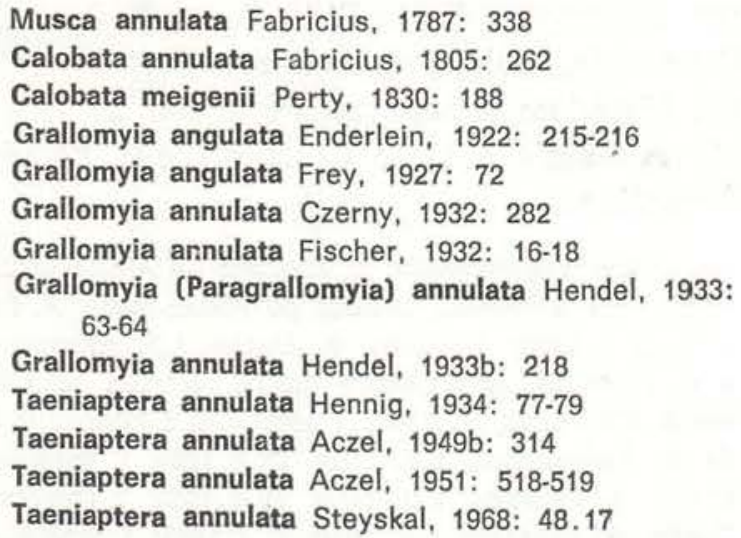

Macho - Comprimento em média $9,2 \mathrm{~mm}$. Corpo basicamente castanho-escuro. Cabeça (Fig. 26) subglobosa, mais larga que longa. Frontália bem delimitada. Mesofronte fusiforme, castanho avermelhada, na porção mediana fica a lâmina ocelar castanho-escura brilhante e ocelos claros; anterior a lâmina ocelar, man- cha castanho aveludada que se alonga até a margem anterior da mesofronte, ligeiramente enrugada e protuberante. Epicéfala ligeiramenie protuberante, castanha com pruinosidade prateada difusa. Paracefala castanha com pequenas setas distribuídas que continuam pelo occiput circundando o forâmen. Gena estreita, com pruinosidade prateada marginando os olhos, 6 pequenas setas próximo à abertura bucal $€$ pequenos pêlos adicionais. Antena: esclerito basilar castanho-brilhante. Primeiro e segundo artículo antenal castanho, com pequenas setas superficiais e marginais e uma seta mais desenvolvida, na face ventral do segundo artículo; terceiro artículo o mais desenvolvido, coberto de curta pilosidade com reflexos prateados. Arista dorsal com a base castanhoclara, escurecendo distalmente. Facialia castanho-clara e densa pruinosidade prateada. Pe ças bucais: anteclípeo castanho moderadamente brilhante pruinosidade esparsa. Palpos labiais castanho-escuros, margem anterior clara com pequenas setas. Premento castanho, com pequenas setas superficiais e maiores nas margens. Setas da cabeça: 2 pares orsa o anterior ligeiramente proclinado e o posterior paralelo; 1 par orss paralelo, 1 par vti e 1 par vte paralelo, 1 par pvt ligeiramente divergente.

Tórax - Basicamente castanho-escuro com reflexos de pruinosidade dourada. Pleuras castanho-escuras com reflexos prateados. $\mathrm{Na}$ margem posterior da esternopleura pente esternopleural formado de 13 setas marginais bem desenvolvidas e setas menores adicionais. Escutelo dorsalmente coberto de densa pruinosidade dourada e prateada, que se estende ao pós-escutelo protuberante, forrado de pruinosidade dourada e prateada. Pronoto castanho brilhante. Propleura e calo umeral castanho-claro. Setas do tórax: tufo de setas propleurais, 2 pares de setas notopleurais subiguais, 1 par de supra-alar e 1 par de pós alar, 1 par dorsocentral pre-escutelar, 1 par escutelar apical ligeiramente convergente. Pernas: coxa I, II e III castanho-escuros, densa pruinosidade prateada e pequenas cerdas enfileiradas na margem anterior. Primeiro par, fêmur, tíbia e tarso basilar com ápice castanho, os demais tarsos brancos; segundo par castanho, 
com anel subapical branco no fêmur, terceiro par castanho com a base e o anel subapical do fêmur branco, tarsos castanhos com pêlos ventrais de reflexos dourados. Asas tendo em média $7,2 \mathrm{~mm}$ de comprimento por $2,1 \mathrm{~mm}$ de largura, base clara, seguida de uma faixa cinza que vai da $r_{2+3}$, faixa clara curva, ápice da asa escuro. Veia $m$ após a $m+c u$ descreve um encurvamento em forma de $S$ bem característico. Célula posterior variavelmente aberta (Fig. 27). Halter conforme a Fig. 28.

Abdome - basicamente castanho-escuro (Fig. 29). Tergitos: tergito I ligado ao II, com setas claras, finas, superficiais e as mais de. senvolvidas laterais. Fila de setas a um terço da faixa de junção dos segmentos onde há setas escuras. Neste sulco vestigial, há condensação de pruinosidade prateada que se estende ao tergito II alargado na margem distal. Nos demais tergitos pequenas setas estão distribuidas e enfileiradas na margem distal, limitando uma faixa membranosa clara. Esternitos: esternito I com a base alargada, vai se estreitando até unir-se ao esternito II que apresenta área basal membranosa mediana. Esternito III e IV estreitos marginados por fino sulco; esternito V desenvolvido, curvo, castanho-escuro, pequenas setas que aumentam em número e tamanho na extremidade distal que é bifurcada e ligeiramente convergente no ápice. Pequena apófise dorsal na base das bifurcações. Esternito VI afilado na extremidade proximal que se insere junto à base do esternito $\mathrm{V}$ servindo-lhe de suporte. O esternito VI alarga-se na margem distal, ligando-se ao esternito VII que é uma estreita trave transversal. Na extremidade, essa trave toca o VII tergito rudimentar e de posição lateral em relação aos demais segmentos. Pós-abdome (Fig. 30); tergitos IX e $X$ formam o epândrio castanho-claro, superficialmente piloso, com pequenas setas, as mais desenvolvidas dispostas na margem. Cercos ocupam a margem posterior do IX segmento. Genitália (Fig. 31) esternito IX em forma de arco dorsal incompleto. Das extremidades desse arco partem duas traves para a base do segmento, soldam-se logo a seguir, formando uma placa mediana esclerosada, reforçada por estrias que não chegam às laterais. Essa placa forra a superfície ventral do segmento no sentido distal, essas traves têm um pequeno alongamento que se articula à extremidade lateral do tergito IX. Apódema do falo de base alargada e quitinosa, o prolongamento distal forma a teca de porção mediana esclerosada, sendo lateral e ventralmente membranosa; com ornamentações superficiais e pequenas setas implantadas em fileiras longitudinais. A teca, articula-se a porção basilar do falo por uma placa semicircular aberta ventralmente; essa porção do falo é sustentada por uma trave dorsal esclerosada de onde parte a membrana que forma a porção lateral fechando-se na face ventral. Esse segmento termina em uma cápsula consistente, esclerosada, que sustenta a porção terminal do falo, com aproximadamente a metade do comprimento da porção basilar que também é membranosa. Apódema do duto ejaculador preso a um pedúnculo consistente pigmentado, que se alonga e alarga progressivamente em leque, tornando-se mais claro. $\mathrm{Na}$ base do pedúnculo, em posição central, há uma formação em cacho semelhante a uma glându. la. Da base parte o duto ejaculador de diâmetro volumoso que percorre a teca, atravessa o anel de articulação, segue a porção basilar do falo, passa através da cápsula quitinosa e vai formar o ápice extremamente membranoso (Fig. 32).

Fêmea - Comprimento em média de 10,4 $\mathrm{mm}$. A asa com a média de $7,45 \mathrm{~mm}$ de comprimento por $2,35 \mathrm{~mm}$ de largura. Abdome (Fig. 33) castanho. Ovipositor (Fig. 34); esternito VII estreita placa circundada por membrana com dois espiráculos e lateralmente descendo até à altura mediana do segmento. Superfície dorsal convexa, base alargada que vai se es. treitando distalmente. A um terço do ápice. constrição pronunciada que reduz a sua largura. Tênue camada de pruinosidade prateada dorsal que se condensa próximo à constrição. Genitália (Fig. 35); duto das espermatecas de consistência esclerosada e parede estriada. A extremidade proximal do duto é marcada por uma ampola que o divide em dois pedúnculos progressivamente menos consistentes, fortemente enrugados e com circunvoluções acentuadas: que desaparecem próximo à inserção da espermateca oval, ricamente estriada com 
invaginação no ápice muito acentuada. Próxi. mo à extremidade distal do duto comum, parto um fino tubo que se alarga progressivamente até a uma ampola que reduz sensivelmente o diâmetro e sustenta a espermateca rudimentar, alongada, esclerosada de superfície enru- gada e espinhosa. O duto comum continua distalmente membranoso, na face ventral duas traves esclerosadas sustentam os cercos de forma bem marcada, setas superficiais carac. terísticas em número, tamanho e implantação. para cada espécie (Fiq. 36).
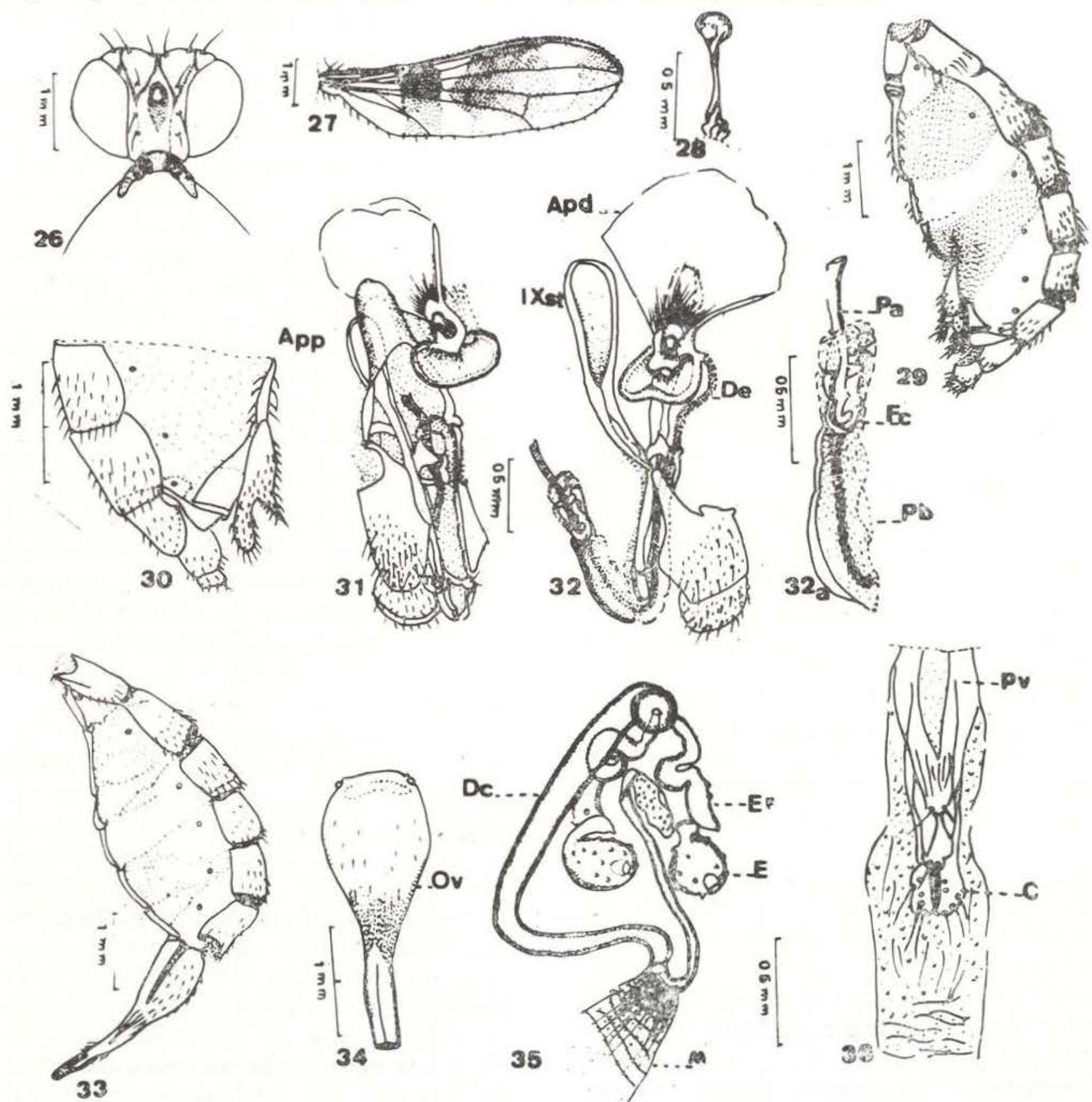

Fig. 26-36 - Taeniaptera annulata (Fabricius, 1787). Macho: 26 - cabeça, vista dorsal; 27 - asa; 28 - halter; 29 abdome, vista lateral esquerda; 30 - pós abdome; 31 - genitália, vista lateral direita; 32 - detalhe da genitália, vista lateral; $32 a-$ aedeago. Fêmea: 33 - abdome, vista lateral esquerda; 34 - ovipositor, vista dorsal; 35 - genitália, dutos e espermateca; 36 - genitália, porçāo distal. (Apd = apódema do duto; App = apódema do edeago; $\mathrm{Dc}=$ duto comum; $\mathrm{De}=$ duto ejaculador; $\mathrm{E}=$ espermateca; $\mathrm{Er}=$ espermateca rudimentar; $\mathrm{Fc}=$ formação capsular; $\mathrm{M}=$ membrana; $\mathrm{Ov}=$ ovipositor; $\mathrm{Pa}=$ porção apical; $\mathrm{Pb}=$ porção basal; $\mathrm{Pf}=$ pinças fálicas; $\mathrm{Tp}=$ teca do edeago; IX st. $=$ nono esternito). 
Distribuição geográfica conhecida: Suriname, Guiana Francesa, Uruguai, Paraguai, Argen. tina, Brasil (do Estado de Santa Catarina ao Estado do Amazonas).

Material examinado: AMAZONAS - Manaus, 1 fêmea, R. Ducke, A. Faustino, 7.3.68; 1 fêmea, Estrada Aleixo-Mauá, A. Faustino, 30.3.68; 1 fêmea R. Ducke, E.V. Silva, A. Faustino, 3.5.1968; 1 macho, R. Ducke, L.P. Albuquerque, 13.5.68; 2 fêmeas, Estrada do Aleixo, E.V. Silva, 29.5.68; 2 fêmeas, Estrada AM-1 Km 155, E.V. Silva, A. Faustino, 2.7.1968; 2 machos e 1 fêmea, R. Ducke, A. Faustino, E.V. Silva, 4.7.1968; 2 fêmeas, R. Ducke, A. Faustino, 3.7.68; 1 macho, Estrada AM-1 Km 155, E.V. Silva, A. Faustino, 11.7.1968; 4 fêmeas, R. Ducke, E.V. Silva, A. Faustino, 2-3.8.1968; 1 fêmea, Estrada BR-174 (antiga BR-17) E.V. Silva, 5.8.1968; 1 macho e 3 fêmeas, R. Ducke, A. Faustino, 14.9.1968; 2 fêmeas, R. Ducke, A. Faustino, 1968; 1 fêmea, R. Ducke. A. Faustino, X. 1968; 1 fêmea, Estrada BR-174 Km 38, E.V. Silva, 7.7.1968; 1 macho e 1 fêmea, Estrada AM-1 16-17.7.1969; 7 fêmeas, Estrada BR-174, (antiga BR-17) Km 38, 5-17.8.1969; 4 fêmeas, R. Ducke, A. Faustino, 14.8.1969; 2 fêmeas, Estrada BR-174 (antiga BR-17) E.V. Silva, 9-10.8.1969; 1 fêmea, Estrada BR-17 Km 38, E.V. Silva, 17.8.1969; 1 macho e 2 fêmeas, Colônia Santo Antonio, A. Faustino, 27.7.1970; 4 fêmeas, Estrada AM-1 Km 15, 19-20.7.1970, A. Faustino: 1 fêmea, Campus do INPA, E. Rufino, 19.5.1979; 1 fêmea, Estrada Aleixo, E. Rufino, 11.5.1977; 1 fêmea, Estrada BR-174 Km 63, L.P. Albuquerque, 28.3.1977; Tabatinga, 1 fêmea, Campus do INPA. F.B. Almeida e A. Faustino, 3.9.1969. PARÁ 1 fêmea, Belém. F. Novaes, 8.3.1959; 1 macho, M. Goeldi, Belém, H.S. Lopes, 6.1965; 1 macho, Mocambo, Belém. A. Sovel, 5.10.1965; 1 fêmea, Utinga, T. Waldir, 9.1965; 1 fêmea, Faz. Oriboca, T. Pimentel, 3.10.1969; 1 fêmea, S. Caetano, Oliveira e Pimentel, 2.6.1970; 1 macho, do M. Goeldi, M. Helena, 12.4.1972; 1 fêmea, Belém-Brasilia Km 90, M. Helena, 28.7.1972; 1 macho, Belém-Brasilia Km 90, M. Helena, 30.7.1972; 1 macho, Utinga, Belém, T. Pimentel, 7.5.1977; 1 macho, M. Goeldi, A.Y. Harada, 14.5.77; 1 fêmea, Tumucumaque, Migliase, 8.1965. BRASÍLIA -1 macho, Brasília-DF, H.S. Lopes, 1961. BAHIA -1 macho, Salvador, S. Oliveira, A. Jesus. SUL DO ESTADO DO RIO DE JANEIRO - 1 macho, Palmeiras, H.S. Lopes, 7.1.1939; 1 fêmea, Palmeiras, H.S. Lopes, 7-11.3.1940; 1 macho e 1 fêmea, Faz. Pinedo, Rezende, H.S. Lopes, 21.7.1959.

\section{Taeniaptera teresacristinae $\mathrm{sp} . \mathrm{n}$.}

Macho - Comprimento total em média de $9,5 \mathrm{~mm}$. Cabeça (Fig. 37) subglobosa. Mesofronte fusiforme, ligeiramente intumescida, castanho escura avermelhada e brilhante; sua maior largura está ao nível da orsa, estreitando-se progressivamente, até atingir a margem posterior da fronte. Frontália castanho-brilhan- te. Parafrontália bem delineada, no limite com a epicéfala, mancha castanho-escura, clareando para a porção anterior que é enrugada $e$ brilhante. Epicéfala e Paracéfala castanho escuras, opacas, nitidamente protuberantes na implantação da vte. Occiput castanho-ferruginoso, opaco, pequenas e numerosas setas, próximo à inserção do pescoço. Gena coberta de densa pruinosidade prateada, de 4 a 6 pequenas setas, próximo à abertura bucal. Parafaciália castanho-clara, estreita, coberta de densa pruinosidade prateada. Faciália castanho. amarelada, pruinosidade difusa, micropêlos superficiais, e faixa castanha marginando a boca. Fossa antenal castanha com reflexos de pruinosidade clara. Antena - esclerito basilar brilhante, artículos I e II, com pequenas setas superficiais e que se alinham na margem anterior. Artículo III o mais desenvolvido, com pilosidade de refiexos claros. Arista clara na base, escurecendo para o ápice. Peças bucais: palpos maxilares castanhos, margem anterior amarelo clara, pêlos superficiais escuros. Clipeo castanho claro com pruinosidade prateada e difusa. Premento castanho, pequenas setas superficiais e marginais, sendo as anteriores mais desenvolvidas. Setas da cabeça: 1 par orsa e 1 par orss paralelas, 1 par vti proclinadas, 1 par vte ligeiramente divergente, 1 par pvt ligeiramente convergente.

Tórax - Pronoto castanho-escuro brilhante, propleura com pruinosidade cinza e pêlos marginais claros. Noto cinza escuro com pruinosidade ferruginosa que se condensa nos sulcos laterais mesonotais e prateada distribuida em toda superfície. Calo umeral e propleura castanho-escuro com reflexos de pruinosidade prateada. Setas torácicas: 9 propleurais pe quenas e finas na margem anterior, 2 pares notopleurais e 2 pares dorsocentrais subiguais, 1 par supralar e 1 par pós-alar paralelas, 1 par escutelar apical. Pente esternopleural formado de 15 setas marginais desenvolvidas e outras menores implantadas anteriormente, intercaladas de pêlos claros. Na face ventral da esternopleura, anterior à inserção do segundo par de pernas de 3 a 6 setas dispostas em linha transversal. Asa (Fig. 38), três setas na veia costal dirigidas para a face ventral dorsal e costal respectivamente, a base hialina, faixa 
escura transversa sobre o pedúnculo da cu+an, seguida de faixa hialina cobrindo a $r-m$, larga faixa escura em posição mediana e estreita faixa clara com a margem basal reta e apical encurvada, seguida pelo ápice da asa escuro. Pernas: coxa I, II e III cinza, pruinosidade clara, concentrada na face anterior, com uma fileira de setas desenvolvidas na margem distal da coxa $a_{1}$ e coxa $a_{2}$; finos pêlos superficiais e densa pruinosidade prateada. Trocanteres castanho escuros brilhantes. Perna I: fêmur castanho, clareando na face ventral; tíbia castanho no ápice; tarsos brancos. Pernas II: fêmur castanho ligeiramente claro na base e os demais segmentos castanho-escuros. Perna III: base do fêmur e anel distomediano amarelado, a proporção entre a largura do anel para a largura do fêmur é de 2:3; tíbia e tarsos castanho-escuros, no ápice da tíbia alcançando a base do tarso, pêlos com reflexo dourado na face ventral. Halter (Fig. 39).

Abdome - (Fig. 40) tergitos basicamente cinza-escuros com reflexos intercalados de pruinosidade avermelhada, que se estende à membrana basal do segmento I (Fig. 41). O terço distal do primeiro segmento é marcada por uma fila de setas longas, finas e claras, sendo algumas escuras no encontro da margem lateral e distal; a junção dos tergitos I e II é marcada por um sulco coberto de densa pruinosidade prateada que se estende ao terço basal do segundo segmento, o mais longo. A superfície dos tergitos II ao VI é coberta de setas finas, curtas, mais desenvolvidas na margem posterior, limitando o bordo membranoso e claro dos segmentos. Na margem basal do tergito III ao $\mathrm{VI}$, há uma área mediana, semicircular de membrana mais clara, tergito VIi reduzido a estreita placa lateral. Tergito VIII castanho, coberto de fina pruinosidade clara, finas e pequenas setas superficiais. Tergito IX forma o epândrio coberto de pilosidade clara conforme (Figs. 42 e 43) com setas superficiais que se concentram nas margens laterais. Esternitos: (Fig. 44) o I alargado na base, estreitando-se para a extremidade distal. Esternito II com área mediana membranosa, esternitos III e IV reduzido a pequenas placas estreitas, esternito V (Fig. 45), desenvolvido em processo copulatório, duplo, estreito na base, porção mediana dilatada e encurvada, margem distal bifurcada com as extremidades convergentes. Pequenas setas escuras, espinhos curtos e que se condensam para a extremidade das bifurcações. Esternito VI estreito na base que se implanta próximo à base do esternito $\mathrm{V}$, servindo-Ihe de suporte, porção distal alargada, une-se ao esternito VII, estreita trave. que se alonga para a face esquerda, indo unirse ao tergito VII rudimental e lateral. Genitália (Fig. 46), anel do esternito IX bem constituido com extremidades alongadas, vão unir-se ao tergito IX, essas extremidades alongam-se para a direção basilar em traves que se unem formando uma placa mediana que forra ventralmente o segmento. Apódema do falo alongado, consistente na base, continua para a porção distal em forma de calha esclerosada ao longo da porção mediana, as laterais da calha são extremamente membranosas com uma fila de setas de número e tamanho bem característico. A um terço da extremidade da calha partem dois braços laterais que sustentam na sua extremidade as pinças fálicas, pequenas placas encurvadas com um par de cerdas subiguais. A porção basilar do falo articula-se à teca por uma placa estreita em forma de anel incompleto ventralmente, que permite o dobramento do órgão quando em repouso. Essa porção do falo é membranosa e sustentada por uma trave esclerosada e bífida distalmente, terminando em uma formação capsular quitinosa; a extremidade do órgão é larga e extremamente membranosa. Apódema do duto, de base capsular quitinosa, bordas estriadas, continuando em um pedúnculo quitinoso que vai alargando-se tornando-se pouco pigmentado e hialino. Parte da cápsula o duto ejaculador consistente, estriado, percorre a formação em calha, passa pelo anel de articulação, pela porção basal do falo, atravessa a formação capsular e vai formar a porção distal sustentando a membrana (Fig. 47).

Fêmea - idêntica ao macho. Comprimento médio $10,6 \mathrm{~mm}$. Abdome (Fig. 48). Esternito (Fig. 49), sendo o esternito VI alargado e ligeiramente triangular. Ovipositor (Fig. $50 \mathrm{e}$ 51) com esclerito ventral, basilar, estreito, circundado de membrana com um par de espirá- 
culos laterais. Essa membrana se alonga até à altura mediana do segmento. Genitália (Fig. 52 e 53), duto principal das espermatecas moderadamente volumoso, com ligeira ampoia na extremidade de onde o duto se bifurca inicialmente com diâmetro fino, dilatando-se logo a seguir tornando-se volumoso com superfície ligeiramente espinhosa e espinhosa e estriada,

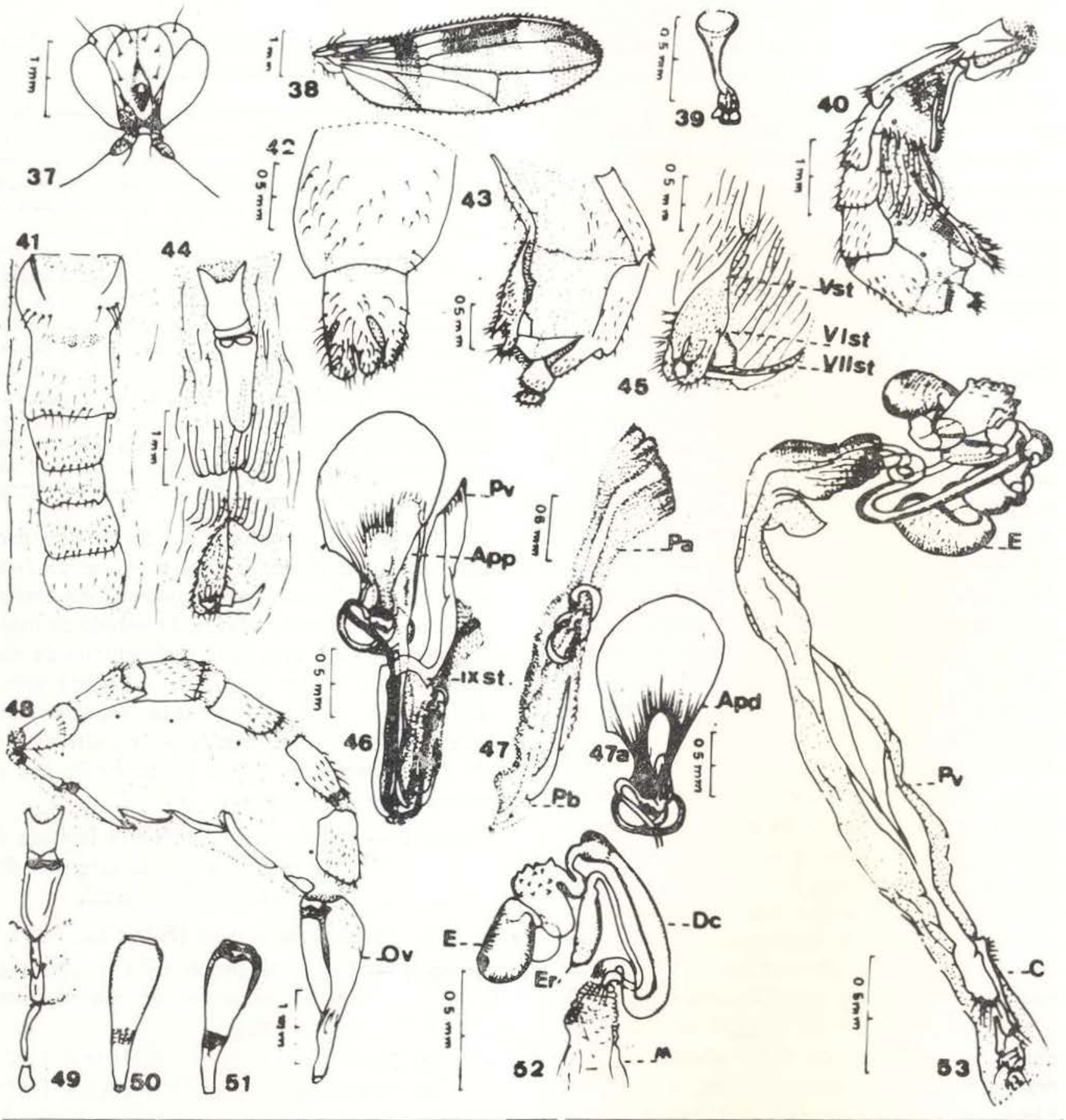

Fig. 37-53 - Taeniaptera teresacristinae sp. n. Macho: 37 - cabeça, vista dorsal; 38 - asa; $39-$ halter; $40-$ abdome, vista lateral esquerda; 41 - tergitos I-VI; 42 - pós abdome, vista lateral esquerda; 44 - esternitos I-VII: 45 - esternitos V-VII; 46 - genitália, vista lateral direita; 47 - aedeago; $47 a$ - apódema do duto ejaculador. Fêmea: 48 - abdome, vista lateral esquerda; 49 - esternito I-VI; 50 - ovipositor, vista dorsal; 51 - idem, vista ventral; 52 - genitália, espermateca e dutos; 53 - genitália. (Apd = apódema do duto: App = apódema do edeago: $\mathrm{Dc}=$ duto comum; $\mathrm{De}=$ duto ejaculador; $\mathrm{E}=$ espermateca; $\mathrm{Er}=$ espermateca rudimentar; $\mathrm{Fc}=$ formaçăo capsular; $\mathrm{M}=$ membrana; $\mathrm{Ov}=$ ovipositor; $\mathrm{Pa}=$ porção apical; $\mathrm{Pb}=$ porção basal; $\mathrm{Pf}=$ pinças fálicas; $\mathrm{Tp}=$ teca do edeago; $\mathrm{V}$ st. = quinto esternito; $\mathrm{VI}$ st. = sexto esternito; VII st. = sétimo esternito; IX st. = nono esternito). 
formando circunvoluções acentuadas, sustenta na extremidade uma espermateca volumosa, finamente enrugada com nítida invaginação apical. Da extremidade do duto comum, parte um duto secundário de calibre reduzido e comprimento considerável, que sustenta a espermateca rudimentar, alongada, extremamente esclerosada, e de superfície enrugada. $O$ duto principal continua distalmente membranoso e ricamente ornamentado. No terço distal, duas traves correm ventralmente e sustentain na extremidade distal os cercos de forma bem marcada, setas características em número tamanho e implantaçăo, para cada espécie. Na base dos fórcipes uma fila de pequenas setas.

\section{Diagnose diferencial}

Taeniaptera teresacristinae aproxima-se de $T$. annulata, $T$. angulata e $T$. albibasis, pelo tamanho do corpo, pela cor castanho-escura, com pruinosidade dourada em toda superfície, pelo esternito $V$ do macho, duplo, pelo ligeiro er. rugamento na porção anterior da parafrontália; separa-se porém, pela paracéfala protuberante no ponto de implantação da vte, pelo castanho opaco da epicéfala e paracéfala, pelo se. gundo par de patas, totalmente castanho, pela condensação da pruinosidade avermelhada que se espaiha do noto e se condensa na sutura mesonotal, lateralmente, dando reflexos dourados. Genitália do macho apresenta diferença nas apófises laterais do esternito IX que se ligam próximo à base, o que dá um aspecto mais alongado à placa mediana ventral, resultante desta fusão, a qual forra o segmento. Há uma fila contínua de finas setas na membrana no esternito IX. A placa dorsal quitinosa do segmento basilar do falo tem a base bifurcada e a porção terminal do órgão é alongada tendo a extremidade do duto ejaculador dilatada, a base do apódema do duto é alongada. Fêmea - aproxima-se de $T$. albitarsis pelo alargamento do esternito VI. Distingue-se de todas as espécies, porém, pelo diâmetro reduzido do duto comum das espermatecas funcionais, dilatação mediana com uma área distintamente quitinizada, enrugada e espinhosa; pelo alongamento do pedúnculo da espermateca rudimentar e pela forma desta espermateca, pela fileira de pequenos pêlos em posição mediana na base dos fórcipes.

A minha filha Teresa Cristina Toledano Salgado, dedico esta espécie.

Distribuição geográfica conhecida: Brasil (Estado do Amazonas, Manaus).

Material examinado: AMAZONAS - Manaus, Holótipo macho, alótipo fêmea, Reserva Florestal Ducke, Mn. AM Brasil, L. P. Albuquerque, 26.4,1968; Parátipos, 1 macho e 20 fêmeas. 1 macho, Estrada BR-174 antiga BR-17), Km 38, E.V. Silva, 7.8.1969; 1 fêmea, Reserva Ducke, Mn. AM Brasil, L.P. Albuquerque, 26.4.78, (dissecada para desenho da genitália, depois montada em lâmina definitiva com Caedax); 1 fêmea, Reserva Ducke, Estrada AM-010 Km 26, E.V. Silva e A. Faustino, 18.6.68; 1 fêmea, Estrada AM-010 K 155, E.V. Silva, 2.8.1968; 1 fêmea, Estrada BR-17, E.V. Silva, 30.8.1968; 1 fêmea, Colônia Sto. Antonio, Estrada AM-010, A. Faustino, 27.7.1970; 1 fêmea, Estrada AM-010, Km 26 L. Albuquerque; 1 fêmea, Estrada AM-010, K 31 CEPLAC, L. Albuquerque, 18-19.8.1977; 1 fêmea, Estrada AM-010, Km 26, Reserva Ducke, L.P. Albuquerque, 11.3.1978; 2 fêmeas, Estr. AM-010, Km 26, L.P. Albuquerque, 26.4.1978.

Posição das espécies - Procura-se dar uma visão de conjunto das espécies de Taeniaptera estudadas nesta seqüência de trabaIhos sobre o gênero, através do estudo da morfologia externa e com base na anatomia da genitália, onde há caracteres de relevante valor sistemático; reunindo-se essas espécies em três grupos naturais, com apoio na alternativa de dois caracteres: Célula posterior da asa e quinto esternito do macho.

Grupo I - Célula posterior da asa fechada e pedunculada e quinto esternito do macho sem apófise basal.

1. Taeniaptera lasciva (Fabricius, 1794)

Grupo II - Célula posterior da asa aberta e quinto esternito do macho sem apófise basal.

2. Taeniaptera albitarsis (Enderlein, 1922)

3. Taeniaptera tarsata (Wiedemann, 1830)

4. Taeniaptera tibialis (Macquart, 1843)

5. Taenlaptera aliceae (Albuquerque, 1980b)

6. Taeniaptera inpai (Albuquerque, 1980b) Grupo III - Célula posterior da asa aberta e quinto esternito do macho com apófise basal 


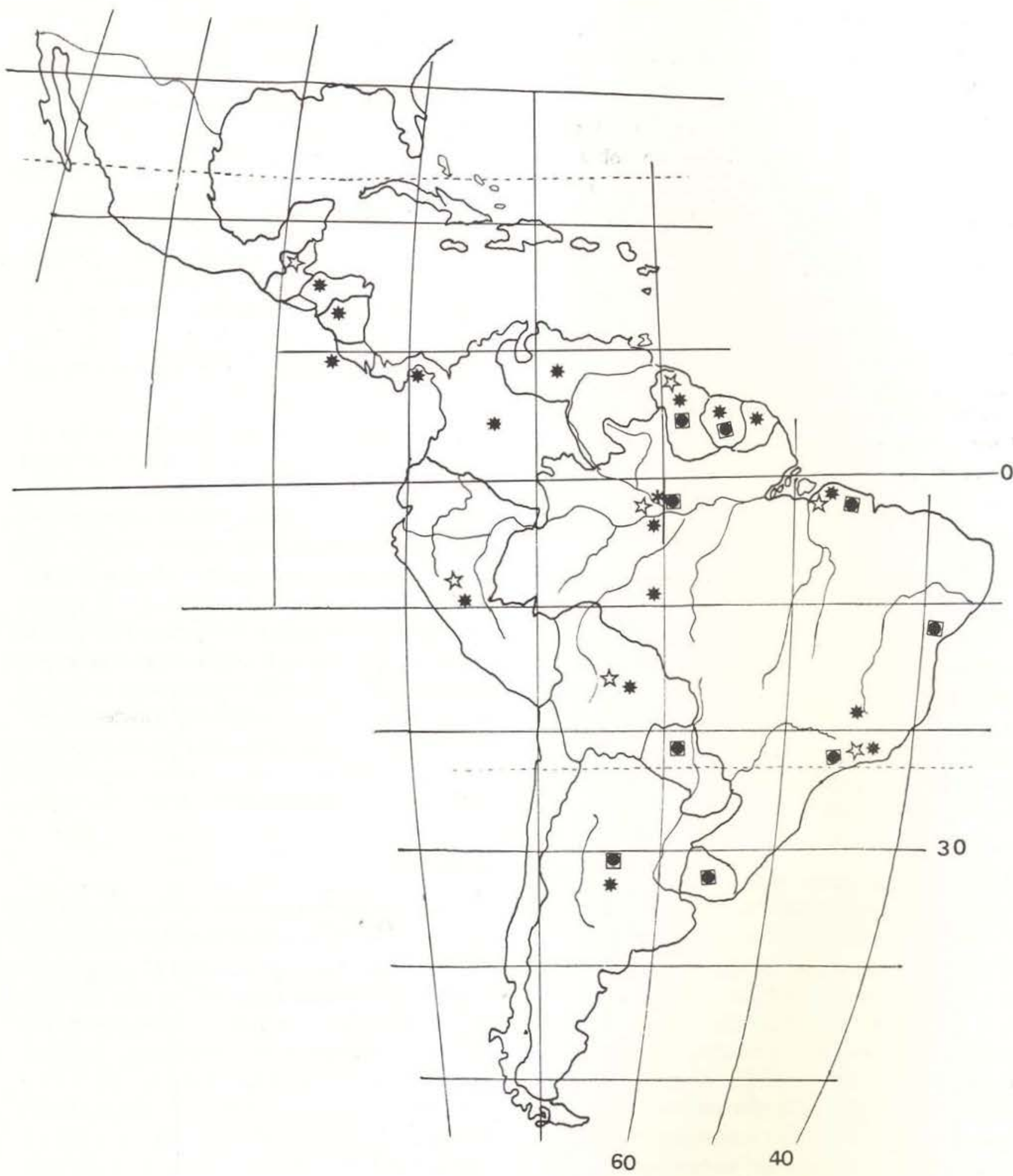

Fig. 54 - Mapa de distribuiçâo geográfica das espécies : ( 2 ) - Taeniaptera albibasis (Enderlein) 1922; ( $)$ Taeniaptera angulata (Loew) 1866; ( ) - Taeniptera annulata (Fabricius) 1787: (*) - Taeniaptera teresacristinae $s p$. n. A frequeência do gênero está condensada na faixa tropical americana. Através de coletas registrou-se sua presença em vários ambientes amazônicos. Amazônia Central: Mata Alta, Capoeira, Bosque, Campina, Campinarana, Baixio e Igapó. 
7. Taeniaptera albibasis (Enderlein, 1922)

8. Taeniaptera angulata (Loew, 1866)

9. Taeniaptera annulata (Fabricius, 1787)

10. Taeniaptera teresacristinae sp. $\mathrm{n}$.

$\mathrm{O}$ pequeno número de Taeniaptera estuda. do na seqüência de nossos trabalhos sobre o gênero, em relação ao tntal de espécies existentes neste gênero, não permite uma avaliação filogenética para uma visão de conjunto; No quadro I a seguir, observa-se grande des continuidade na manifestação de um caráter. Atribui-se estes claros entre as espécies, como espaços que deverão ser preenchidos à medida que aumente o número de espécies conhecidas na região. As espécies no (Quadro I) estão ordenadas pelo número e sequiência das espécies no agrupamento acima.

\section{Discussão}

Endem \& Hennig (1970) em estudo comparativo das importantes diferenças na estrutura básica entre a genitália de Nematócera e Brachicera, utilizam como um dos exemplos o pós-abdome de Calobata cibaria L (Micropezidae), discutem as homologias das peças da genitália das duas subordens. Nesta seqüência de trabalhos sobre Micropezidae, tem-se adotado em parte essa nomenclatura.

As espécies $T$. albibasis, $T$. angulata e $T$. annulata, apresentam grande semelhança entre si, mas há caracteres isolados bem distintos que possibilitam confirmar a identidade de cada uma delas. Enderlein (1922) e Frey (1927), descreveram essas espécies somente por alguns caracteres da morfologia externa e colocaram $T$. angulata e $T$. annulata reciprocamente na sinonimia. Há porém diferenças bem marcantes na genitália dessas espécies, que permitem uma separação com boa margem de segurança embora não se tenham examinado os "Tipos". T. angulata apresenta expansões laterais pontiagudas na base do esternito $\mathrm{V}$, alargamento lateral posterior do tergito II, bem pronunciado; a base do apódema do duto bem alargada; espermatecas funcionais ovaladas. pedúnculo das espermatecas rudimentares curto. T. annulata sem expansões laterais do esternito $\mathrm{V}$; alargamento látero-posterior do tergito II pouco pronunciado, membrana do ápice do falo nitidamente enrugada; espermate. cas funcionais arredondadas de superficie espinhosa com pedúnculo dilatado e embricado.

As áreas da cabeça nos seus limites são coincidentes com aquelas delimitadas por Hennig (1936 Taf. 1:105); o quinto esternito de $T$. angulata e $T$. annulata, (Taf. 3:107); também semelhantes às peças correspondentes no material aqui trabalhado. Quanto ao aedeago, apenas foi possível comparar o de $T$. albibasis fig. 12:71 (Hennig, 1936) com o material em exame.

T. teresacristinae sp. n. embora muito semelhante às espécies anteriores na morfologia externa, separa-se pela paracéfala protuberante que juntamente com a epicéfala apresentam cor castanho-escura, ferruginosa, opaca, até quase à inserção do pescoço. Fêmur II totalmente castanho-claro. Esternito I e II alargado em ambos os sexos, trave dorsal da porção basal do ŕalo vestigial, duto comum das espermatecas muito dilatado e espinhoso, o que se nota também no corpo das espermatecas, tornando-as bem características, fila de pequenos pêlos em escova na base dos fórcipes, em posição vertical mediana (Fig. 53).

\section{CoNCLUSÃo}

A reunião de espécies de Taeniaptera em grupos naturais para facilidade de estudo, possibilita uma visão de conjunto e o inter-reia. cionamento dessas espécies na sua morfologia; e, a inclusão em determinados grupos das espécies redescritas, ou assinaladas como no. vas para a ciência, no desenvolvimento do estudo desse gênero. Durante as coletas, foram assinalados para essas espécies os mais variados habitats, tais como: Mata Alta, Bosque, Capoeira, Baixio, Campina e Campinarana. Quanto ao regime alimentar, observou-se através da atração pelas iscas oferecidas, e alimentação natural do meio, hábitos sacrófilo, micófilo e coprófilo, em indivíduos das espé. cies aqui estudadas. 
Espécies

\begin{tabular}{|c|c|c|c|c|c|c|c|c|c|c|}
\hline Caracteres & 1 & 2 & 3 & 4 & 5 & 6 & 7 & 8 & 9 & 10 \\
\hline 1. Célula posterior da asa fechada & + & - & - & - & - & - & - & - & - & - \\
\hline 2. Asa de cor uniforme & 一 & 一 & - & - & + & - & - & - & - & - \\
\hline 3. Mancha hialina posterior em meia-lua & + & - & - & - & - & - & - & - & - & - \\
\hline 4. Paracéfala protuberante e opaca & 一 & 一 & - & - & - & - & - & - & 一 & + \\
\hline 5. Terceiro e quarto esternitos vestigiais & - & 一 & - & 一 & + & - & - & - & - & 一 \\
\hline 6. Um par de cerdas orsa & - & - & + & - & 一 & - & - & + & - & - \\
\hline 7. Um par de cerdas dorso-central & + & - & + & - & - & 一 & 一 & + & + & - \\
\hline 8. Mancha castanha pós-umeral & - & + & + & - & + & + & - & - & - & - \\
\hline 9. II tergito mais largo que longo & - & + & + & + & + & - & - & - & - & - \\
\hline 10. Cerdas do $2 .^{\circ}$ segmento antenal desenvolvida & - & + & - & + & - & - & - & + & - & - \\
\hline 11. Mesofronte alargada & + & - & + & + & + & - & - & - & + & - \\
\hline 12. II esternito maior que o III + IV & + & - & - & + & - & - & + & + & + & + \\
\hline 13. V esternito do macho sem apófises basais & + & + & + & + & + & + & - & - & - & - \\
\hline 14. VI esternito da fêmea alargado & + & - & + & + & + & - & - & - & - & + \\
\hline 15. Ovipositor curto & + & - & + & - & 一 & + & + & + & + & + \\
\hline 16. Cerdas supra-umerais vestigiais & + & - & + & + & + & - & + & + & + & 一 \\
\hline 17. 2 espermatecas funcionais e 2 vestigiais & - & - & + & - & - & - & - & - & - & - \\
\hline 18. 3 espermatecas desenvolvidas & - & - & - & - & - & - & - & - & - & + \\
\hline 19. 2 espermatecas funcionais e 1 vestigial & + & + & - & + & + & + & + & + & + & - \\
\hline 20. Espermateca vestigial com pedúnculo longo & - & - & + & - & - & + & - & - & - & + \\
\hline 21. Espermateca vestigial com pedúnculo médio & - & - & - & - & - & - & + & + & + & - \\
\hline 22. Ducto comum espermatecas enrugado & + & - & + & + & + & - & - & - & - & - \\
\hline 23. Pedúnculo espermatecas funcionais enrugado & + & + & - & + & + & - & + & + & + & + \\
\hline 24. Edeago curto & 一 & + & + & + & + & + & + & + & + & + \\
\hline 25. Anel do IX esternito desenvolvido & - & + & + & + & - & + & + & + & + & + \\
\hline 26. Placa ventral do IX esternito desenvolvida & - & + & + & + & - & + & + & + & + & + \\
\hline
\end{tabular}

Estudo... 


\section{SUMMARY}

The study of Taeniaptera Macquart, 1835, continues with the redescription of $\mathbf{T}$, albibasis (Enderlein, 1922); T. angulata (Loew, 1866); T. annulata (Fabricius, 1787); and the description of a species new to science, T. teresacristinae, based on external morfology and genital anatomy of both sexes. The geographical distribution of the genus is centered in the American tropics. The occurence of these species bridges various types of amazonian habitats.

\section{REFERENCIAS BIBLIOGRÁFICAS}

ACZEL, $M$.

1949a - Notes on "Tylidae", II. Acta Zool. Lilloana, 8: 219-280, pls. $1-2$.

1949 - Catálogo de la familia de las "Tylidae" (Calobatidae - Micropezidae + Neriidae, Diptera) en la region neotropical. Acta Zool. Lilloana, 8: 309-389.

1951 - Morfologia externa e division sistemática de las "Tanypezidiformes". Acta Zool. Lilloana, 11: 483-589, pls. 1-4.

ALBUQUERQUE, L.P.

1980a- Estudo dos Micropezideos da Bacia Amazônica - I Contribuição à Sistemática de Micropezidae e estudo do gênero Taeniaptera. Acta Amazonica, 10 (3): 659-70.

1980b- Estudo dos Micropezideos da Bacia Amazônica - II Redescrição de três espécies e conhecimento de duas espécies novas para a ciência de Taeniaptera Macquart, 1835 (Diptera-Micropeidae). Acta Amazonica, 10 (4): 863-881.

CRESSON, E.T. Jr.

1908 - Dipterological notes. I. Micropezidae. Trans. Amer. Ent. Soc., 34: 1-12, pls. 1-2.

1930 - Note on and description of some neotropical Neriidae and Micropezidae (Diptera). Trans. Amer. Ent. Soc., 56: 307-363.

CZERNY, L.

1930 - Die Musca annulata F. (Dipt. Micropez.) Mitteil. Deutsch. Ent. Ges., 1 (8): 117-120.

1932 - Tyliden und Neriiden des zoologischen Museums in Hamburg (Dipt.) Stettin. Ent. Ztg. 93: 267-302.

ENDEM, F. van \& HENNIG, W.

1970 - In S.L. Tuxen ed. Taxonomist's Glossary of Genitalia in insects, 2nd. ed. Copenhagen, Munkagaard.

ENDERLEIN, G.

1922 - Klassifikation der Micropeziden. Arch. Na. turg. $88(\mathrm{~A}): 140-229$
FABRICIUS, J.C.

1787 - Mantissa insectorum sistens species nuper delectas Hafniae (=Copenhagen). 2382pp.

1794 - Supplementum entomologiae systematical Hafniae (=Copenhagen). 572pp.

1805 - Systema antliatorum secundum ordines, genera, species. Bunsvigae (=Brunswick). 373 $+30 \mathrm{pp}$.

FISCHER, C.R.

1932 - Contribuição para o conhecimento da metamorphose e posição systematica da familia Tylidae (Micropezidae, Dipt.) Rev. de Ent., 2: 15-24.

FREY, R.

1927 - Zur Systematik der Diptera Haplostomata III. Micropezidae. Notulae Ent., 7: 65-76.

HENDEL, F.

1933a- Ueber einige Typen Wiedemann's und Schiner's von acalyptraten Musciden aus Südamerika, nebst einige verwandten Arten (Dipt.,). Rev. de Ent., 3: 58-83.

HENNIG, W.

1934 - Revision der Tyliden (Dipt., Acalypt.,) I. Teil: Die Taeniaptera Amerikas. Stetiin. Ent. Ztg., 95: $65-108$ pls. 3 .

1936 - Do. II. Teil: Die aussereuropäischen Taeniapterinae, die Trepidariinae und Tylinae. Allgemeines über die Tyliden (cont.). Konowia, 15: 129.236.

LOEW, $\mathrm{H}$.

1866 - Diptera America setentrionalis indigena. Centuria septima. Berlin. Ent. Zts. 10: 1-54.

MACQUART, J.

1835 - Histoire naturelie des insects. Diptères. 2: 703pp., pls. 13-24 (In N.E. Roret, ed.: Collection des Suites à Buffon).

1843 - Diptères exotiques nouveaux ou peu connus. (3e. Subdivision). Min. Soc. Roy. Sci. Agric. Arts. Lille 1842: $162-460$, ps. 1-36.

PERTY, M.

1830 - Delectus animalium articu.atorum, etc. (3rd part): Monachii. 125-224, pls. 25-40.

STEYSKAL, G.C.

1968 - A catalogue of Diptera of the Americas South of the United States. Family Micropezidae. Dep. Zool. Sec. Agric. Est. São Paulo. 48: 1-33

VANZOLINI, P.E. et alii

1967 - Manual de Coleta e Preparação de Animais Terrestres e de Água Doce Dep. Zool. Sec. Agric. Est. S. Paulo, 227pp.

WIEDMANN, C.R.W.

1830 - Aussereuropäische zweiflügelige Insekten 2: XII + 684pp., 5 pls. Homm.

(Aceito para publicação em $26 / 10 / 80$ ) 